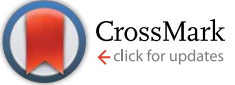

Cite this: RSC Adv., 2017, 7, 12518

Received 19th January 2017

Accepted 16th February 2017

DOI: $10.1039 / \mathrm{c} 7 \mathrm{ra00805h}$

rsc.li/rsc-advances

\title{
Chemoenzymatic epoxidation of alkenes with Candida antarctica lipase B and hydrogen peroxide in deep eutectic solvents $\dagger$
}

\author{
Pengfei Zhou, ${ }^{a}$ Xuping Wang, ${ }^{\mathrm{b}}$ Bo Yang, ${ }^{\mathrm{a}}$ Frank Hollmann ${ }^{\mathrm{c}}$ and Yonghua Wang ${ }^{\star b}$ \\ Epoxides are important synthetic intermediates for the synthesis of a broad range of industrial products. This \\ study presents a promising solution to the current limitation of enzyme instability. By using simple deep \\ eutectic solvents such as choline chloride/sorbitol, significant stabilization of the biocatalyst has been \\ achieved leading to more robust reactions while using environmentally more acceptable solvents as \\ compared to ionic liquids.
}

\section{Introduction}

Epoxides are important synthetic intermediates in the production of many industrial products. ${ }^{1}$ Next to established chemical syntheses such as the Prileshajev epoxidation using stoichiometric peracids ${ }^{2}$ or metal-catalyzed epoxidations, ${ }^{3,4}$ enzymatic $^{5-9}$ and chemoenzymatic methods ${ }^{\mathbf{1 0 - 1 2}}$ have also gained relevance. Particularly, the latter methods are attractive due to the broad availability of hydrolases. In essence, chemoenzymatic methods rely on the in situ formation of a reactive peracid making use of the 'perhydrolase' promiscuous activity of many lipases. The peracids formed react with the alkene forming the product of interest and re-forming the carboxylic acid, which enters a new catalytic cycle (Scheme 1). ${ }^{\mathbf{1 3}}$

A broad range of hydrolases has been investigated for the perhydrolysis of carboxylic acids or their esters with hydrogen peroxide to produce epoxides. ${ }^{14-18}$ Among them the lipase B from Candida antarctica (CalB), immobilized onto an acrylic resin (tradename Novozym 435), is probably the most-widely used biocatalyst. ${ }^{19}$ Several studies dealing with lipasecatalyzed in situ peracid formation to promote the Prileshajev epoxidation underline the preparative potential of this approach..$^{\mathbf{2 0}-23}$

In recent years, it has become clear that CalB suffers from a pronounced instability against the harsh conditions of the chemoenzymatic epoxidation reaction as compared to the 'natural' esterification reactions. Arends and coworkers

${ }^{a}$ School of Bioscience and Bioengineering, South China University of Technology, Guangzhou 510006, P. R. China

${ }^{b}$ School of Food Science and Engineering, South China University of Technology, Guangzhou 510640, P. R. China. E-mail: yonghw@scut.edu.cn; Fax: +86 (0)20 8711 3842; Tel: +86 (0)20 87113842

'Department of Biotechnology, Delft University of Technology, Van der Maasweg 9, 2629HZ, Delft, The Netherlands

$\dagger$ Electronic supplementary information (ESI) available. See DOI: 10.1039/c7ra00805h reported that ionic liquids (ILs) could substantially improve the performance of chemoenzymatic Baeyer-Villiger and epoxidation reactions. ${ }^{24}$ The authors suggested a two-fold effect of hydrogen-bond-donor-ILs in the reaction: first by stabilizing the biocatalyst and second, by accelerating the reaction through solvent-activation of the peracid.

Though frequently termed 'green solvents' (mostly due to their non-volatility), ILs are actually questionable from an environmental point-of-view. ${ }^{25}$ For example, toxicity issues can impair the environmental friendliness as well as the sometimes rather complex and resource-consuming synthesis (vide infra). Therefore, it is not astonishing that current research efforts focus on environmentally less demanding substitutes such as (natural) deep eutectic solvents (DESs).

The number of studies evaluating DESs as more environmentally acceptable alternatives to ILs is steadily increasing. ${ }^{26}$ For example, beneficial effects of DESs on lipase-catalysed esterification reactions have been reported. ${ }^{27-29}$ Inspired by these very promising reports, we set out to investigate the possible beneficial effects of DESs on the chemoenzymatic epoxidation reaction.

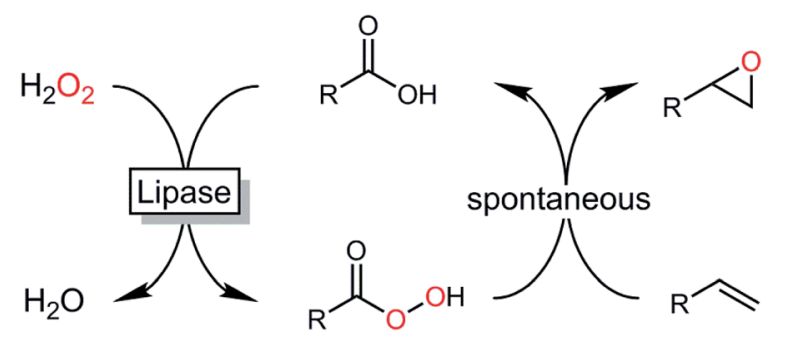

Scheme 1 Chemoenzymatic epoxidation reaction using in situ generated peracids. In the first step, lipase-catalyzed perhydrolysis of a carboxylic acid with $\mathrm{H}_{2} \mathrm{O}_{2}$ forms the corresponding peracid, which then, in a non-enzymatic Prileshajev reaction forms the epoxide and the (catalytic) carboxylic acid. 


\section{Results and discussion}

In a first set of experiments, we evaluated the influence of various DESs of the efficiency of the chemoenzymatic epoxidation of 1-octadecene as a model reaction (Table 1).

From the nine DESs chosen for this experiment, the aminebased DES gave the poorest results. Essentially product formation ceased already after approx. $6 \mathrm{~h}$. Possibly, inactivation of the enzyme (maybe due to deprotonation of structurally essential amino acid residues) accounted for this behavior. Polyolbased DESs gave significantly higher robustness and consequently also higher product titers. Hence, $\mathrm{ChCl} /$ sorbitol as solvent resulted in more than $70 \%$ conversion of the starting material. This effect has also been observed by Arends and coworkers who have pointed out the importance on hydrogenbond-donating cosolvents (ILs) on the stabilization of the protein structure. ${ }^{24}$ Similarly, Diego et al. have emphasized the importance of polyols such as sorbitol on protein structure. ${ }^{30}$

Encouraged by these results, we became interested in shedding some more light on the beneficial and detrimental effect of amine-based or polyol-based DESs on the stability of the biocatalyst. Therefore, the apparent half-life times of CalB in the presence of different solvents were determined (Fig. 1). In accordance to our previous observation, ${ }^{31}$ the amine-based DESs significantly reduced (as compared to buffer as incubation solvent) the stability of CalB over the entire temperature range investigated whereas the polyol-based DESs significantly increased the stability of the biocatalyst.

The effect of the single solvents on the structural integrity of CalB was investigated in some more detail using circular dichroism spectroscopy (CD). As shown in Table 2, the relative amount of secondary structure elements within the enzyme decreased to some extent after incubation in phosphate buffer for $24 \mathrm{~h}$, while in $\mathrm{ChCl} /$ urea almost all secondary structural

Table 1 Epoxidation of 1-octadecene in different DESs ${ }^{a}$

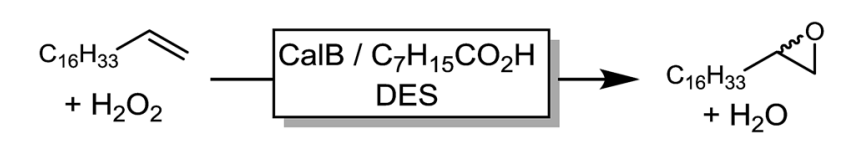

\begin{tabular}{lll}
\hline & & Conversion \\
Entry & Solvents (molar ratio) & 30.2 \\
\hline 1 & $\mathrm{ChCl} /$ urea $(1: 2)$ & 13.9 \\
2 & $\mathrm{ChCl} /$ acetamide $(1: 2)$ & 37.7 \\
3 & $\mathrm{ChCl} /$ ethylene glycol $(1: 2)$ & 56.7 \\
4 & $\mathrm{ChCl} /$ glycerol $(1: 1)$ & 65.1 \\
5 & $\mathrm{ChCl} /$ xylitol $(1: 1)$ & 72.4 \\
6 & $\mathrm{ChCl} /$ sorbitol $(1: 1)$ & 58.4 \\
7 & $\mathrm{ChCl} /$ xylose/water $(5: 2: 5)$ & 65.3 \\
8 & $\mathrm{ChCl} /$ glucose/water $(5: 2: 5)$ & 56.2 \\
9 & $\mathrm{ChCl} /$ sucrose/water $(5: 2: 5)$ & 62.5 \\
10 & Phosphate buffer $(\mathrm{pH} 6.0,50 \mathrm{mM})$ &
\end{tabular}

${ }^{a}$ Conditions: octadecene $(1.6 \mathrm{mmol})$, octanoic acid $(1.6 \mathrm{mmol})$ and $\mathrm{H}_{2} \mathrm{O}_{2}$ (1.6 mmol added as $30 \% \mathrm{w} / \mathrm{w}$ solution) were reacted in different DESs at $40{ }^{\circ} \mathrm{C}$ using Novozym $435(100 \mathrm{mg})$ as catalyst for $24 \mathrm{~h}$ with magnetic stirring $(300 \mathrm{rpm})$.

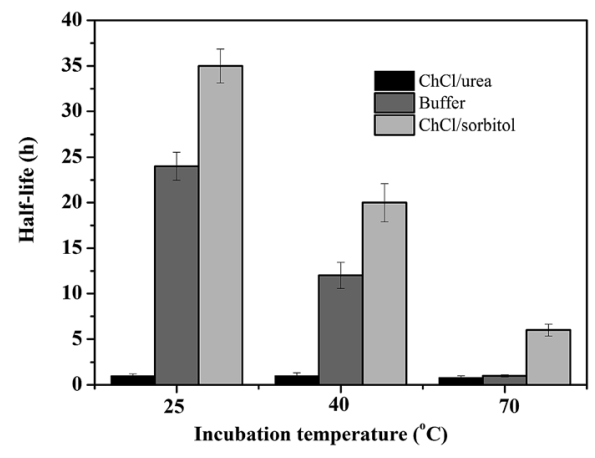

Fig. 1 CalB stability (displayed as half life time) at different temperatures in the presence of buffer, $\mathrm{ChCl} /$ urea and $\mathrm{ChCl} /$ sorbitol.

elements disappeared at the benefit of random coil. On the contrary, secondary structure elements were almost entirely preserved (as compared to the freshly dissolved enzyme) upon incubation of the enzyme in $\mathrm{ChCl} /$ sorbitol. This result is also in agreement with our previous study. ${ }^{31}$ Hence, we conclude that the increased stability of the enzyme was due to the preservation of its structural integrity in $\mathrm{ChCl} /$ sorbitol.

Next, the key parameters effecting the chemoenzymatic epoxidation reaction; particularly the influence of the reaction temperature, the octanoic acid concentration and the hydrogen peroxide concentration were investigated (Fig. 2).

Quite expectedly, initial this reaction rate increased linearly with temperature (Fig. 2A). Hence, the rate-limiting step may be diffusion of either the enzyme substrates (octanoic acid and/or $\mathrm{H}_{2} \mathrm{O}_{2}$ ) or products (peroctanoic acid). It is worth pointing out here that in similar studies Törnvall et $a .^{32}$ reported a sharp decrease of the enzyme activity at $60{ }^{\circ} \mathrm{C}$. This underlines the stabilizing effect of $\mathrm{ChCl} /$ sorbitol on the enzyme.

The initial rate of the overall reaction showed a saturationtype behavior with respect to the concentration of octanoic acid used (Fig. 2B). Above $1.6 \mathrm{mmol}$ of octanoic acid, no significant increase of the initial rate was observed. This may be due to the Michaelis-Menten-type kinetics of the lipasecatalyzed perhydrolysis reaction with octanoic acid. However, it should be pointed out that in these experiments we could

Table 2 Secondary structure percentages of CalB after incubation in different media

\begin{tabular}{lllll}
\hline & $\begin{array}{l}\alpha- \\
\text { helix } \\
\text { Medium }\end{array}$ & $\begin{array}{l}\beta- \\
\text { strand } \\
{[\%]}\end{array}$ & $\begin{array}{l}\text { Turn } \\
{[\%]}\end{array}$ & $\begin{array}{l}\text { Random coil } \\
{[\%]}\end{array}$ \\
\hline Initial CalB $^{a}$ & 19.8 & 13.4 & 31 & 35.8 \\
$\mathrm{KP}_{\mathrm{i} \mathrm{buffer}}{ }^{b}$ & 12.3 & 17.5 & 33.5 & 36.7 \\
$\mathrm{ChCl}^{c}$ urea $^{c}$ & 2.2 & 1.3 & 34.3 & 62.2 \\
$\mathrm{ChCl} /$ & 16.6 & 19.1 & 32.5 & 32
\end{tabular}

sorbitol $^{d}$

${ }^{a}$ Determined directly after complete dissolution of the enzyme.

${ }^{b}$ Conditions: CalB incubated in $50 \mathrm{mM} \mathrm{pH} 6.0$ phosphate buffer.

${ }^{c}$ Conditions: CalB incubated in $\mathrm{ChCl} / \mathrm{urea}$ and. ${ }^{d}$ Conditions: CalB incubated in $\mathrm{ChCl} /$ sorbitol at $30{ }^{\circ} \mathrm{C}$ for $24 \mathrm{~h}$. 


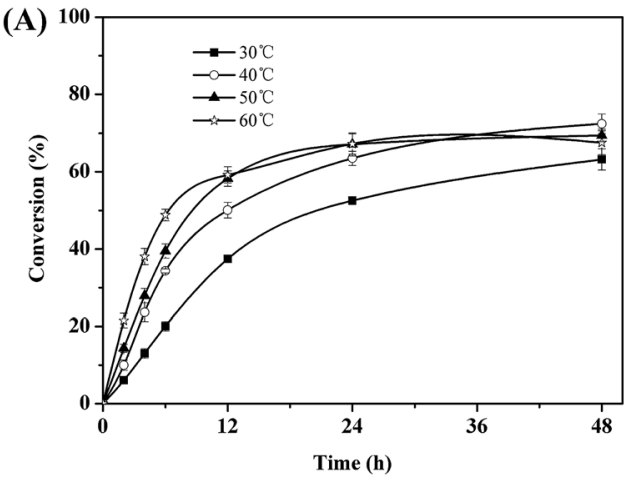

(B)

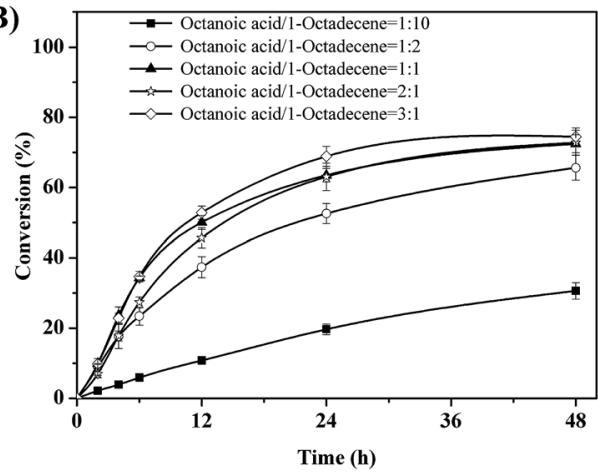

(C)

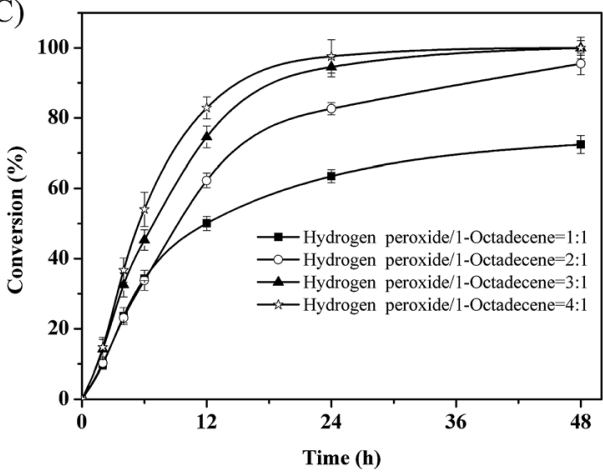

Fig. 2 Effects of temperature (A), molar ratio of octanoic acid to 1octadecene (B) and molar ratio of hydrogen peroxide to 1-octadecene molar ratio $(\mathrm{C})$ on the epoxidation of 1-octadecene.

demonstrate that octanoic acid performs as catalyst $(\mathrm{TN}=3)$, pointing towards a truly catalytic system. Nevertheless, for all further experiments we used a molar ratio of $1: 1$ (acid : alkene) in order not to impair the overall reaction rate. Again, the maximal conversion reached in these experiments was approx. $70 \%$.

Interestingly, the amount of hydrogen peroxide applied to the reaction system had almost no influence on the initial rate of the reaction (which may be explained by a comparably low $K_{\mathrm{M}}$ value for $\mathrm{H}_{2} \mathrm{O}_{2}$ ) (Fig. 2C). But it had a very significant influence on the overall conversion reached. At a nominal molar ration of 1: $1\left(\mathrm{H}_{2} \mathrm{O}_{2}\right.$ to alkene) the maximal conversion observed in all experiments so far was approx. $70 \%$. However, already at a molar ratio of $2: 1\left(\mathrm{H}_{2} \mathrm{O}_{2}\right.$ to alkene) full conversion was achieved. We believe that the most likely explanation for this observation may be that the active $\mathrm{H}_{2} \mathrm{O}_{2}$ content of the stock solution may have been significantly lower (approx. 70\%) than the nominal concentration. Further experiments clarifying this issue are currently underway.

We also evaluated the substrate scope of this partially optimized reaction system. As shown in Table 3, a range of (ali) cyclic alkenes as well as styrene derivates were converted in good to excellent conversions in high selectivity as confirmed by NMR analysis of the isolated products (see $\mathrm{ESI} \dagger$ for details). Only trace amounts (is any) of possible degradation (isomerization or hydrolysis) products were detectable.

The performance of the proposed chemoenzymatic reaction system using $\mathrm{ChCl} /$ sorbitol as 'performance additive' compares well with similar reactions reported in the literature. ${ }^{31}$ For example, the conversion of 1-octadecene in aqueous reaction media was $68 \%$ or $30 \%$ using the lipase from Penicillium camembert $^{33}$ or the lipase from Malassezia globosa ${ }^{34}$ respectively. In a three-phase system of water/methyl dichloride/ionic liquid, the conversion of cyclohexene was $41 \%{ }^{18}$ Therefore, the new oxidation system proposed here represents a promising approach for preparative epoxidation reactions.

To further understand the molecular basis of the perhydrolysis reaction we modelled octanoic acid and $\mathrm{H}_{2} \mathrm{O}_{2}$ into the active site of CalB (Fig. 3). Carbonyl atom of the octanoic acid is bound in the oxyanion hole of the enzyme by two hydrogen bonds to the amide nitrogens of Gln106 and Thr40. The distance between carbonyl atom of octanoic acid and $\mathrm{O} \gamma$ of Ser105 is $2.9 \AA$, which is facilitate to nucleophilic attack carbonyl group by Ser105 in active site to form an acetyl-enzyme intermediate. Simultaneously, $\mathrm{H}_{2} \mathrm{O}_{2}$ is stabilized in the active site by Gln157, Asp134 and His224. Then, hydrogen peroxide attacked acetyl-enzyme intermediate to achieve perhydrolysis reaction. This mechanism is similar to previous reports. ${ }^{33-35}$

Table 3 Substrate scope of the optimized chemoenzymatic epoxidation system ${ }^{a}$

$\begin{gathered}\text { Reaction time } \\ {[\mathrm{h}]}\end{gathered}$
$\begin{gathered}\text { CalB } / \mathrm{C}_{7} \mathrm{H}_{15} \mathrm{CO}_{2} \mathrm{H} \\ \mathrm{DES}\end{gathered}$

\footnotetext{
${ }^{a}$ General conditions: $0.4 \mathrm{~g}$ ChCl/sorbitol, $100 \mathrm{mg}$ Novozym 435, $1.6 \mathrm{mmol}$ octanoic acid, $1.6 \mathrm{mmol}$ alkene and $3.2 \mathrm{mmol} 30 \mathrm{wt} \% \mathrm{H}_{2} \mathrm{O}_{2}$ at $40{ }^{\circ} \mathrm{C}$ with magnetic stirring $300 \mathrm{rpm} .{ }^{b} \mathrm{~T}=30^{\circ} \mathrm{C}$.
} 


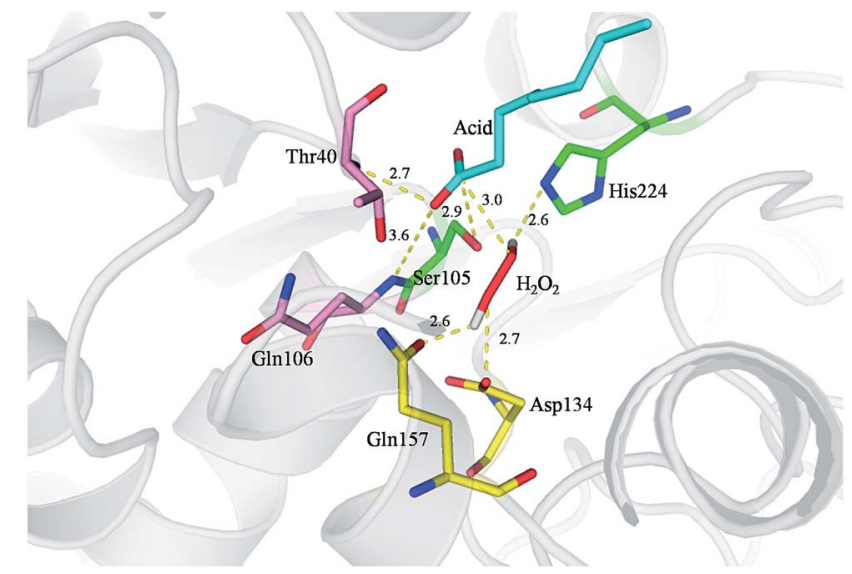

Fig. 3 The mode of CalB (PDB ID: ILBT) catalyzed epoxidation mechanism. The atom of hydrogen, oxygen and nitrogen are shown in white, red and blue, respectively. Hydrogen bonds are shown in yellow dash with distances in angstroms.

Finally, we performed a preliminary evaluation of the environmental impact of the chemoenzymatic epoxidation reaction. For this, the Sheldon's E-factor (environmental factor) analysis was used (eqn (1)) $)^{36,37}$ and compared our chemoenzymatic epoxidation of styrene with a similar reaction reported by Arends and coworkers. ${ }^{24}$

$$
\text { E-factor }=\frac{\sum m(\text { waste products })[\mathrm{kg}]}{m(\text { product })[\mathrm{kg}]}
$$

Eqn (1) calculation of Sheldon's E-factor.

It becomes clear from Table 4, that the solvent (either $\mathrm{ChCl} /$ sorbitol or $\left.[\mathrm{BMIM}]\left[\mathrm{BF}_{4}\right]\right)$ has a very significant impact on the Efactor of the reaction contributing $31 \%$ or even $75 \%$ to the total value, respectively.

Given this importance of the solvents, also their upstream processing should be considered. Following Jessop's approach of evaluating the environmental impact of solvent synthesis based on the synthesis trees ${ }^{38}$ we compared those for [BMIM] $\left[\mathrm{BF}_{4}\right]$ and $\mathrm{ChCl} /$ sorbitol (Fig. $\mathrm{S} 1 \dagger$ ). This comparison reveals that

Table 4 E-factor analysis

\begin{tabular}{lll}
\hline Entry & DESs system $^{a, b}$ & ILs system $^{a 24}$ \\
\hline $\begin{array}{l}\text { Non-converted } \\
\text { (styrene) conversion (\%) }\end{array}$ & $0.016 \mathrm{~g}(0.09) 90 \%$ & $0.08 \mathrm{~g}(1) 40 \%$ \\
CalB (biocatalyst) & $0.1 \mathrm{~g}(0.58)$ & \\
Octanoic acid & $0.23 \mathrm{~g}(1.35)$ & $0.01 \mathrm{~g}(0.13)$ \\
Solvent & $0.4 \mathrm{~g}(\mathrm{ChCl} /$ sorbitol) & $1 \mathrm{~g}\left([\mathrm{BMIM}]\left[\mathrm{BF}_{4}\right]\right)$ \\
& $(2.35)$ & $(12.5)$ \\
$\mathrm{H}_{2} \mathrm{O} / \mathrm{H}_{2} \mathrm{O}_{2}$ & $0.56 \mathrm{~g}(3.29)$ & $0.14 \mathrm{~g}(1.75)$ \\
Product & $0.17 \mathrm{~g}$ & $0.08 \mathrm{~g}$ \\
E-factor & 7.7 & 16.7
\end{tabular}

${ }^{a}$ Numbers in parentheses represent the individual E-factor contributions (i.e. $\mathrm{g}$ component $\times \mathrm{g}$ product -1 ). ${ }^{b}$ Results taken from Table 3. compared to $[\mathrm{BMIM}]\left[\mathrm{BF}_{4}\right]$ (30 steps) the synthesis of $\mathrm{ChCl}$ / sorbitol with only 10 steps is significantly less complex. Furthermore, most of the solvent $(55 \% \mathrm{w} / \mathrm{w})$ of $\mathrm{ChCl} /$ sorbitol originates from renewable resources. Of course, only a full life cycle assessment (LCA) will be suitable to holistically compare the environmental impact of the solvent syntheses and the chemoenzymatic reactions, but we hold the results from this preliminary analysis to be very encouraging.

\section{Conclusions}

In the present study, it has been demonstrated that DESs represent a true alternative to the commonly used ILs to facilitate the chemoenzymatic epoxidation of alkenes. The system excels particularly by the lower environmental impact of the cosolvents (DESs) used as compared to ILs. This advantage, however, does not come with an impaired performance compared to classical ILs. The practical applicability and efficiency of the current system is at least as good as the one of the systems of the state-of-the-art. Therefore, we are convinced that exciting future developments will arise from the application of DESs to chemoenzymatic epoxidation reactions.

\section{Experimental sections}

\section{Materials}

Candida antarctica lipase B (CalB, Novozym 435-immobilized on a polyacrylate resin) was obtained from Novo Nordisk (Denmark). The $30 \%(\mathrm{w} / \mathrm{w})$ hydrogen peroxide, choline chloride (98\%), urea (99\%), acetamide (99\%), ethylene glycol (98\%), glycerol (99\%), xylitol (98\%), D-sorbitol (98\%), D-xylose (98\%), D(+)-glucose (99.5\%), sucrose (ACS grade), 1-hexene (99\%), cyclohexene (99\%), 1-decene (99.5\%), 1-octadecene (95\%), styrene (99\%), $\alpha$-methylstyrene (99\%), cyclohexene oxide (98\%) and styrene oxide (98\%) were bought from Aladdin Chemistry Co., Ltd (Shanghai, China). 1,2-Hexylene oxide (98\%), decene oxide (98\%), octadecene oxide (99\%) and $\alpha$-methylstyrene oxide (97\%) were obtained from TCI (Japan). All other reagents were of analytical grade.

\section{Preparation DESs}

Deep eutectic solvents were formulated in different molar ratios of quaternary ammonium salt (choline chloride) to hydrogen bond donors. The eutectic mixtures were prepared by rotary evaporation of the two components at $80^{\circ} \mathrm{C}$ in water bath until a homogeneous transparent liquid was formed.

\section{Stability of enzyme}

Purified CalB enzyme was added into $50 \mathrm{mM}$ phosphate buffer pH 6.0, DESs $\mathrm{ChCl} /$ urea or $\mathrm{ChCl} /$ sorbitol incubated at temperature from $25{ }^{\circ} \mathrm{C}$ to $70{ }^{\circ} \mathrm{C}$ for $12 \mathrm{~h}$. The samples were extracted from reaction mixture at periodically, and then the perhydrolysis activity was followed spectrophotometrically at $290 \mathrm{~nm}$ as described by Peter Bernhardt. ${ }^{39}$ The tests were carried out in 96-well microtiter plates with a reaction of volume $100 \mu \mathrm{L}(80 \mu \mathrm{L}$ assays solution to $10 \mu \mathrm{L}$ samples and $10 \mu \mathrm{L}$ hydrogen peroxide 
in 0.1 M pentanoic acid buffer $\mathrm{pH} 5.0$ ) at $40{ }^{\circ} \mathrm{C}$ for 5 minutes using microplate reader Cytation ${ }^{\mathrm{TM}} 5$ (BioTek, USA). The blank experiments were carried out under the identical conditions adding inactived enzymes. All tests were performed in triplicate.

\section{Epoxidation reaction}

In a $10 \mathrm{~mL}$ Erlenmeyer flask were added $1.6 \mathrm{mmol}$ of 1-octadecene, $1.6 \mathrm{mmol}$ of octanoic acid, $1.6 \mathrm{mmol}$ and $1.6 \mathrm{mmol}$ of $30 \%$ hydrogen peroxide, $0.4 \mathrm{~g}$ of DESs and $100 \mathrm{mg}$ Novozym 435 at $40{ }^{\circ} \mathrm{C}$ stirring with $300 \mathrm{rpm}$. The control without DESs was performed in the phosphate buffer. The $30 \%$ hydrogen peroxide was added in 3 portions in $1 \mathrm{~h}$ intervals. Samples were withdrawn in different time-points. $20 \mu \mathrm{L}$ of solution was added into $980 \mu \mathrm{L}$ methanol and then for gas chromatograph analysis.

\section{Analytical methods}

Analysis of olefins and corresponding epoxides were determined using an Agilent Technology model 7890 GC (Agilent, USA), equipped with an HP-5 column $(30.0 \mathrm{~m} \times 0.25 \mathrm{~mm}, 0.25$ $\mu \mathrm{m}$, Macherey Nagel, Germany). Peak of olefins and corresponding epoxides in GC were identified and calculated by the calibration curves which were made with the reference standard compounds.

\section{Circular dichroism spectroscopy}

Circular dichroism (CD) spectroscopy measurements of protein were carried out with a Chirascan spectropolarimeter (Applied Photophysics, Surrey, UK), using $0.2 \mathrm{mg} \mathrm{mL}^{-1}$ of purified CalB enzyme in different medium. The path length was $0.5 \mathrm{~mm}$. Spectra covering the wavelength range of 190-260 nm were scanned at $25{ }^{\circ} \mathrm{C}$. The scanning rate is $1 \mathrm{~nm}$ per $0.5 \mathrm{~s}$. Each spectrum was the average of three successive scans. Under the same conditions, the corresponding medium solution was recorded as control and subtracted from the sample spectra. The secondary structure percentages were analyzed by using the CDNN tool.

\section{Identification of epoxide}

Epoxidized alkenes was identified by nuclear magnetic resonance (NMR) spectra (Bruker Avance $600 \mathrm{MHz}$ ). Samples were dissolved in $600 \mu \mathrm{L}$ deuterated chloroform in a NMR tube and subjected to ${ }^{1} \mathrm{H}$ and ${ }^{13} \mathrm{C}$ NMR analysis.

\section{Structure analysis}

The modeling of the ligand carboxylic acid in the binding site and complex energy minimization has been performed with MODELLER package (Discovery Studio 3.5). The structure 1LBT and the model of its open conformation ${ }^{40}$ has been used for analysis.

\section{Acknowledgements}

This work was supported by National Natural science foundation of China (31471690). National High Technology Research and Development Program of China (863 program,
2014AA093514, 2014AA093601) and Science and Technology Planning project of Guangdong province (2014B020204003, 2015B020231006).

\section{Notes and references}

1 E. J. De Vries and D. B. Janssen, Curr. Opin. Biotechnol., 2003, 14, 414-420.

2 C. Orellana-Coca, S. Camocho, D. Adlercreutz, B. Mattiasson and R. Hatti-Kaul, Eur. J. Lipid Sci. Technol., 2005, 107, 864870.

3 X. Li, Q. Shen, G. Zhang, D. Zhang, A. Zheng, F. Guan and Y. Sun, Catal. Commun., 2013, 41, 126-131.

4 N. Scotti, N. Ravasio, R. Psaro, C. Evangelisti, S. Dworakowska, D. Bogdal and F. Zaccheria, Catal. Commun., 2015, 64, 80-85.

5 J. B. Park, B. Bühler, T. Habicher, B. Hauer, S. Panke, B. Witholt and A. Schmid, Biotechnol. Bioeng., 2006, 95, 503-505.

6 H. Lin, J. Qiao, Y. Liu and Z. L. Wu, J. Mol. Catal. B: Enzym., 2010, 67, 236-241.

7 S. Peter, M. Kinne, R. Ullrich, G. Kayser and M. Hofrichter, Enzyme Microb. Technol., 2013, 52, 370-376.

8 C. E. Paul, D. Tischler, A. Riedel, T. Heine, N. Itoh and F. Hollmann, ACS Catal., 2015, 5, 2961-2965.

9 C. Zhang, P. X. Liu, L. Y. Huang, S. P. Wei, L. Wang, S. Y. Yang, X. Q. Yu, L. Pu and Q. Wang, Chem.-Eur. J., 2016, 22, 10969-10975.

10 E. G. Ankudey, H. F. Olivo and T. L. Peeples, Green Chem., 2006, 8, 923-926.

11 M. Svedendahl, P. Carlqvist, C. Branneby, O. Allnér, A. Frise, K. Hult, P. Berglund and T. Brinck, ChemBioChem, 2008, 9, 2442-2451.

12 D. Méndez-Sánchez, N. Ríos-Lombardía, V. Gotor and V. Gotor-Fernández, Tetrahedron, 2014, 70, 1144-1148.

13 F. Björkling, S. E. Godtfredsen and O. Kirk, J. Chem. Soc., Chem. Commun., 1990, 1, 1301-1303.

14 B. Meunier, S. P. de Visser and S. Shaik, Chem. Rev., 2004, 104, 3947-3980.

15 J. Littlechild, Curr. Opin. Chem. Biol., 1999, 3, 28-34.

16 A. Li, S. Wu, J. P. Adams, R. Snajdrova and Z. Li, Chem. Commun., 2014, 450, 8771-8774.

17 J. Wu, C. Liu, Y. Jiang, M. Hu, S. Li and Q. Zhai, Catal. Commun., 2010, 11, 727-731.

18 M. A. Moreira, T. B. Bitencourt, M. Graça, M. A. Moreira and T. B. Bitencourt, Synth. Commun., 2005, 35, 2107-2114.

19 E. Milchert, K. Malarczyk and M. Kłos, Molecules, 2015, 20, 21481-21493.

20 T. B. Bitencourt and M. da Graça Nascimento, Green Chem., 2009, 11, 209-214.

21 Y. Xu, N. R. B. J. Khaw and Z. Li, Green Chem., 2009, 11, 20472051.

22 C. Aouf, J. Lecomte, P. Villeneuve, E. Dubreucq and H. Fulcrand, Green Chem., 2012, 14, 2328-2336.

23 C. Aouf, E. Durand, J. Lecomte, M. C. Figueroa-Espinoza, E. Dubreucq, H. Fulcrand and P. Villeneuve, Green Chem., 2014, 16, 1740-1754. 
24 A. J. Kotlewska, F. van Rantwijk, R. A. Sheldon and I. W. C. E. Arends, Green Chem., 2011, 13, 2154-2160.

25 T. Welton, Green Chem., 2011, 13, 225.

26 A. Paiva, R. Craveiro, I. Aroso, M. Martins, R. L. Reis and A. R. C. Duarte, ACS Sustainable Chem. Eng., 2014, 2, 10631071.

27 Q. Zhang, K. De Oliveira Vigier, S. Royer and F. Jérôme, Chem. Soc. Rev., 2012, 41, 7108-7146.

28 K. Xu, Y. Wang, Y. Huang, N. Li and Q. Wen, Anal. Chim. Acta, 2015, 864, 9-20.

29 C. X. Zeng, S. J. Qi, R. P. Xin, B. Yang and Y. H. Wang, Bioprocess Biosyst. Eng., 2015, 38, 2053-2061.

30 T. De Diego, P. Lozano, S. Gmouh, M. Vaultier and J. L. Iborra, Biotechnol. Bioeng., 2004, 88, 916-924.

31 P. Zhou, X. Wang, C. Zeng, W. Wang, B. Yang, F. Hollmann and Y. Wang, ChemCatChem, 2016, DOI: 10.1002/ cctc. 201601483.
32 U. Törnvall, C. Orellana-Coca, R. Hatti-Kaul and D. Adlercreutz, Enzyme Microb. Technol., 2007, 40, 447-451.

33 Q. Tang, G. M. Popowicz, X. Wang, J. Liu, I. V. Pavlidis and Y. Wang, ChemistrySelect, 2016, 1, 836-839.

34 X. Wang, Q. Tang, G. M. Popowicz, B. Yang and Y. Wang, Biochem. Biophys. Res. Commun., 2015, 460, 392-396.

35 D. L. Yin, P. Bernhardt, K. L. Morley, Y. Jiang, J. D. Cheeseman, V. Purpero, J. D. Schrag and R. J. Kazlauskas, Biochemistry, 2010, 49, 1931-1942.

36 R. A. Sheldon, Chem. Commun., 2008, 3352-3365.

37 R. A. Sheldon, Green Chem., 2017, 19, 18-43.

38 P. G. Jessop, Green Chem., 2011, 13, 1391-1398.

39 P. Bernhardt, K. Hult and R. J. Kazlauskas, Angew. Chem., Int. Ed., 2005, 44, 2742-2746.

40 J. Uppenberg, N. Ohrner, M. Norin, K. Hult, G. J. Kleywegt, S. Patkar, V. Waagen, T. Anthonsen and T. Jones, Biochemistry, 1995, 34, 16838-16851. 